\title{
Nurses' Attitude About Pap Smear As An Early Screening Method For Cervical Cancer In The Private Hospital
}

\author{
Marlina Elfrida Sinaga ${ }^{\mathrm{a}}$, Puji Astutik ${ }^{\mathrm{a}}$, Belet Lydia Ingrit ${ }^{\mathrm{a}^{*}}$, Fransiska Ompusunggu $^{\mathrm{a}}$ \\ ${ }^{1,2}$ Faculty of Nursing, Universitas Pelita Harapan \\ Jln Jendral Sudirman Boulevard, Lippo Karawaci, Tangerang, Banten 15811 \\ *e-mail: belet.ingrit@uph.edu
}

\begin{abstract}
.
The prevalence of cervical cancer in Indonesia is very high, which it is estimated that every day 40-45 new cases appear. The purpose of this study was to describe nurses' attitude about pap smear as an early detection of cervical cancer in a hospital in western Indonesia. The research method was used descriptive quantitative with purposive sampling technique. The results of this study shows that most of the respondents have the positive attitude in performing pap smears in the Western Indonesia hospitals with the percentage of $97,5 \%$ and the rest indicate negative attitude. The conclusion of this study is that the positive attitude of nurses towards early detection of pap smears is expected to be maintained and furthermore the hospital continues to provide health facilities for female nurses to carry out early detection of cervical cancer as an annual program from hospital.
\end{abstract}

Keywords: Cervical Cancer, Nurse Attitude, Pap Smear

\section{Introduction}

According to World Health Organization, the number of cancer patients was increase from year to year with an estimated 12 million people in 2030 (WHO, 2015). From 32.4 million of cancer patients today, $52 \%$ of cancer patients are women (International agency for cancer research, 2014). Cervical cancer is the second most common cancer in women worldwide (12\%) following by breast cancer which is the most common cancer among women in developing countries (Urasa and Darj, 2011). Cervical cancer is cervical malignancy caused by infection with the Human Papillomavirus. The National Cancer Management Committee also said that HPV types 16 and 18 are the main cause in $70 \%$ of cervical cancer cases in the world (National Cancer Management Committee, 2014). In Southeast Asia, the incidence of cervical cancer reaches 20-30\% of all cancers (Bal, et al. 2015).

Indonesia is the country with the highest number of cervical cancer sufferers in the world. According to the Indonesian Ministry of Health, it was stated that in 2013, cervical cancer occupied the highest prevalence in Indonesia of $0.8 \%$ (98,692 cases) (Ministry of Health Republic of Indonesia, 2015). As many as approximately 21,000 new cases of cervical cancer are found in Indonesia each year and continue to increase (Afiyati and Pratiwi, 2015). The number of cervical cancer sufferers in Indonesia is very high, it is estimated that every day 40-45 new cases occur, 20-25 people die which means that every hour an estimated one woman dies due to cervical cancer based of Ministry of Health Republic of Indonesia (Ministry of Health Republic of Indonesia, 2015).

Cervical cancer remains as one of the leading causes cancer in women from Indonesia, Malaysia,
Philippines, Thailand and Vietnam. High risk for Human Papilomavirus (HPV) types, particularly HPV-16 and 18, has factors that have been identified to increase the HPV exposure or development of cervical cancer include young age at first intercourse, high parity and multiple sexual partners (Dominggo, 2008). They study said that uptake of screening remains low in all regions and is further compounded by the lack of basic knowledge women have regarding screening as an opporunity for the prevention of cervical cancer. Pap smear has the main goal to detect the appearance of cancer cells in the cervix so that treatment can be done from the start of being diagnosed. The high incidence of cervical cancer both in the world and in Indonesia certainly requires an analysis of nurses 'attitudes in the early detection of cervical cancer in carrying out a pap smear examination.

Even though nurses is health worker and practitioner who have good knowledge about pap smear, however not all of them have good attitude about that. As an initial interview, the researcher conducted interviews in early November 2018 with ten nurses in private hospitals in Western Indonesia about the behavior of early detection of cervical cancer with a pap smear. The results show that five nurses is not doing pap smears for various reasons such as; fear, shame, high costs, and prohibitions from religion and belief. Therefore, this research expects to find out the nurses' attitudes about the initial detection (screening) of pap smears in one hospital private sector in Indonesia.

\section{Method}

This research is a quantitative descriptive study with data collection using purposive sampling technique. A total of 40 female nurses were selected as respondents in this study according to the inclusion 
criteria. They are female nurses with productive age (25 - 45 years) with minimum education level of Diploma III and active nurses engaged in sexual intercourse marked by marital status or had ever been married. Research conducted in private hospitals in Western Indonesia with time of this research was on February until March 2019. Analysis of this data uses in univariate analysis with questionnaire. The questionnaire had been tested for validity and reliability with Cronbach alfa 0.759 .

Four main principles in nursing ethics were used in this research, they are 1). Respect of human dignity by giving informed consent to the respondents, 2 ). Respect for privacy and confidentiality by giving initial name or certain code, so the identity of the respondent is kept confidential from the public, 3) Respect for justice and inclusiveness by giving the explanation and the objectives of the study to respondents, and 4) Balance harm and benefit by minimizing risks that could endanger respondents from the impact caused by conducting this research for all respondents.

\section{Result}

Based on the data obtained from the study to all respondents, nurses in private hospitals in Western Indonesia from the Out-Patient Department (OPD) and In-Patient Department (IPD), there were 40 respondents according to the characteristics they have.

Table 3.1 Demographic characteristics $(n=40)$

\begin{tabular}{lll}
\hline Variable & Frequency & $\begin{array}{l}\text { Percentage } \\
(\%)\end{array}$ \\
\hline Age & & \\
20-30 years & 17 & 42.5 \\
31-40 years & 20 & 50 \\
41-45 years & 3 & 7.5 \\
& & \\
Marital status & & \\
Married & 39 & 97.5 \\
Ever married & 1 & 2.5 \\
& & \\
Education & & 75 \\
Diploma III in & 30 & 25 \\
Nursing & 10 & \\
Undergraduate & & \\
\hline
\end{tabular}

Based on the table above, it is shown that the most frequency of respondents aged 31-40 years (50\%) and the frequency of $20-30$ years is $42.5 \%$ and the rest is just $4.5 \%$ for respondents $41-45$ years. For marital status almost all the respondents are married that is $97.5 \%$ and only one respondent that has ever been married (1\%). The education level of the respondents is $75 \%$ (30 respondents) Diploma III in Nursing and 25\% (10 respondents) is undergraduate.

Tabel 3.2 History of pap smear examination $(n=40)$

\begin{tabular}{lll}
\hline $\begin{array}{l}\text { History of } \\
\text { pap smear }\end{array}$ & Frequency & Persentase \% \\
\hline Ever & 18 & 45 \\
Never & 22 & 55 \\
Total & 40 & 100 \\
\hline
\end{tabular}

Table 3.2 shows that respondents who had taken screening pap smear were 18 respondents or in the amount of $45 \%$. It was stated by respondents only once or twice, and there were 22 respondents or $55 \%$ of the total respondents who had never had a pap smear test.

Table 3. 3 Frequency distribution of nurses' attitudes in conducting pap smears $(\mathrm{N}=40)$

\begin{tabular}{lll}
\hline Category & Frequency & $\begin{array}{l}\text { Percentage } \\
(\%)\end{array}$ \\
\hline Positive & 39 & 97,5 \\
Negative & 1 & 2,5 \\
Total & 40 & 100 \\
\hline
\end{tabular}

Based on the table above as many as 39 respondents or $97.5 \%$ had a positive attitude and only one respondent or as much as $2.5 \%$ had a negative attitude towards the pap smear examination.

\section{Discussion}

Cervical cancer is one of cervical malignancy caused by infection Human Papillomavirus (HPV) (National Cancer Management Committee, 2014). The National Cancer Management Committee also said that HPV types 16 and 18 are the main cause in $70 \%$ of cervical cancer cases in the world (National Cancer Management Committee, 2014). Although cervical cancer is largely preventable through screening, detection and treatment of precancerous abnormalities, it remains one of the top causes of cancer-related morbidity and mortality globally (Musa, et al, 2017). The impact of cervical cancer prevention programs depends on persuading women to go for screening and, if needed, treatment (Young-Mi, et al., 2015).

Based on the results of the study, the description of nurses' attitudes in carrying out early detection of cervical cancer with a pap smear in a private hospital in Indonesia obtained data that most of them have a positive attitude in carrying out a pap smear of 39 respondents with a percentage of $97.5 \%$, and one respondent $(2.5 \%)$ with a negative attitude category. The number of respondents who have a positive attitude category, can be due to the self-awareness of the nurses which has been better by conducting 
early detection of pap smears. However, it is an interesting because the history of respondents who have done pap smears only 18 nurses ( $45 \%$ nurses) and 22 respondents (55\% nurses) have never done a test PAP smear. This is in line with the research conducted by Jain SM, Bagde MN \& Bagde ND in India which stated that most female nurses knew about pap smears $(86.2 \%)$ but only $58.6 \%$ used hospital facilities to conduct early detection of pap smears (Jain, et al., 2016).

Other studies also reinforce the level of good knowledge about cervical cancer does not guarantee health workers to conduct early detection of pap smears (Anantharaman, 2012). Another study in tertiary Hospital in North Eastern India, proved that although knowledge of Pap smear as a screening procedure for cervical cancer is high, practice is still low (Thippeveeranna, 2013). If we can improve the practice of Pap smear screening in such experts, they should be able to readily provide appropriate and accurate information and motivate the general population to join screening programs. Knowledge is needed but does not guarantee to the ability to change someone's behavior, especially the behavior of health workers (nurses) in conducting early detection of pap smears.

Nurses' attitudes toward pap smears are still low even though the knowledge they know about pap smears is quite good. This is reinforced by the results of research conducted by Udigwe (2006) who said that the knowledge of cervical cancer screening services among female nurses is fairly good however the uptake of these screening services by the nurses is very poor. This is also in line with research conducted by Thippeveeranna et al, who said that nurse attitudes is adequate with $91.5 \%$ with knowledge of pap smear as a screening procedure for cervical cancer is high, but practice for pap smear is still low (Thippeveeranna, 2013). Beside that other studies said that most nurses $(84.6 \%)$ had never been pap smear examination (Urasa and Darj, 2011).

Cervical cancer is the third most common cancer among women worldwide with an estimated 83.195 new cases and 35.673 deaths in 2012 (Urasa and Darj, 2011). Primary prevention of cervical cancer aims at reducing the incidence of cervical cancer by controlling the causes as well as risk factors. Despite the active role of health care workers to prevent cervical cancer, there are many obstacles faced by health care workers to promote cervical cancer screening and the main obstacle is as well as poor attitude and practice for cervical cancer screening. Research conducted by Alali et al said that female health worker in primary healthcare in Qatar had a good attitude towards cervical cancer screening but low in practicing (32.2\%) (Alali et., 2016)

Nurses, as the largest group of health workers, have an important role in promotion of cervical cancer screening [16]. Therefore, knowledge and awareness of cervical cancer are the most important for general women, who are educated by nurses. That's way nurse as a role model for the patient, nurse must pay attention to their own health. Good attitude but low practicing in cervical cancer screening (pap smear) will certainly have an impact on their health status. The impact if nurses does not take the pap smear screening, they will not know their health condition. As a role model, educator and also care giver, nurses should have good health, good stamina and the important is have good attitude so they can be good role model for the patient. This is can compare with other research said that most respondents had never pap smear screening is because afraid of the procedure and being afraid of bad results (Urasa and Darj, 2011).

Another study said that there is not significant differences between knowledge or attitudes about cervical cancer risk factors or symptoms and screening methods regarding age, marital status, years of experience (Ertem , 2004). Not only as a nurse in hospital, nurse in academic also have good attitude but low in pap smear practice. This is shown by another study said that $72 \%$ nursing staff aware of pap smear screening but only $16.6 \%$ had ever undergone a pap smear test (Rahman and Kar, 2015). A good attitude toward pap smear examination is followed by attitude in the decision to take pap smear screening. If not accompanied by the decision to conduct pap smear screening will have an impact on the health of female nurses. It has been already proven that the efficiency of regular pap smear screening can reduced the mortality rate of cervical cancer (Ertem , 2004).

Another part that is also important that nurses need knows is HPV vaccination. Human papillomavirus (HPV) is a common sexually transmitted infection that is implicated in $99.7 \%$ of cervical cancers and several other cancers that affect both men and women (Sherman, et al., 2018). HPV immunization is the primary prevention of cervical cancer where the success rate can reach $100 \%$ if given as much as two times on the age group of naive women or women who have never been infected with HPV (Ministry of Health Republic of Indonesia , 2016). Most nurses' support HPV, but their active involvement should not be taken for granted (Duval, et al., 2009). Targeted educational efforts are needed to ensure nurses' involvement in the prevention of HPV related diseases. Assessment of the nursing staff knowledge, attitude and also practices about cervical cancer screening is important especially in 
staff nurses of a tertiary care teaching. this is confirmed by the results of the study of Shekhar, et al, (2013) they said that adequate knowledge of cervical cancer and screening, higher parity and age more than 30 years were significantly associated with self screening for cervical cancer. In India, The majority of nursing staff have inadequate knowledge about cervical cancer screening, and their attitude and practices towards cervical cancer screening could not be termed positive (Shekhar, et al, 2013). Not only in India, but also in Asia like in Thailand, almost all of the registered nurses working at hospital have a moderate level of knowledge regarding cervical cancer and HPV but there are still some major misunderstandings; thus, educational pamphlets, notices and hospital announcements would be useful in increasing their knowledge (Ngawai, 2007).

\section{Conclusion}

The results of this study conclude that most female nurses in one private hospital in Indonesia have a positive attitude in responding to early detection of pap smears, but only a few of them have screened pap smears. The recommendation for the hospital is expected that pap smear screening tests can be an annual hospital program that must be followed by all female employees and nurses both married and never married and are still active in sexual relations.

\section{References}

Alali, A., Salem, M., Elmahdi, H., Alkubaisi, Z., Taher, M., Yousuf, M., Aljaber, A \& Mostafa, A. 2016. Knowledge, attitudes and practices regarding cervical cancer screening among Female Health Care Workers in Primary Healthcare in Qatar. Middle East Journal of Family Medicine, 14 (8): 4-15.

Afiyati, Y \& Pratiwi, A. (2017). Seksualitas dan kesehatan reproduksi perempuan: Promosi, permasalahan dan penanganannya dalam pelayanan kesehatan dan keperawatan. Edisi 1 Cetakan 2. Jakarta: Rajawali Press

Bal, M.S., Goyal, R., Suri, A.K., \& Mohi, M.K. (2012). Detection of abnormal cervical cytology in Papanicolaou smears. J Cytol, 29 (1): $45-7$

Dominggo, E., Noviani, R., Noor, M., Ngelangel, C., Limpaphayom, K., Thuan, T.T., Louie, K.S \& Quinn, M.A. (2008). Epidemiology and Prevention of Cervical Cancer in Indonesia,
Malaysia, the Philippines, Thailand and Vietnam. Vaccine. Vol 26: 71-79.

Duval, B., Gilca, V., Boulianne, N., Pielak, K., Halperin.B., Simpson, M.A., Sauvageau, C., Ouakki. M., Dube. E \& Lavoie. F. 2009. Cervical cancer prevention by vaccination: nurses' knowledge, attitudes and intentions. Journal of Advanced Nursing. 65(3), 499-508 doi: 10.1111/j.1365-2648.2008.04900.x

Ertem, G. 2009. Awareness of Cervical Cancer Risk Factors and Screening Behaviour among Nurses in a Rural Region of Turkey. Asian Pacific Journal of Cancer Prevention, Vol 10, 735-738

International agency for cancer research.Cancer prevention. (2014) Swiss: WHO Press.

Jain SM, Bagde MN \& Bagde ND. (2016). Awareness of cervical cancer and Pap smear among nursing staff at a rural tertiary care hospital in Central India. Indian Journal of Cancer. Volume 53 (1): 63-66

Ministry of Health Republic of Indonesia. Infodatin: Pusat data dan informasi kementerian Kesehatan RI tentang informasi penyakit kanker. Jakarta: Kemenkes Republik Indonesia (2015)

Ministry of Health Republic of Indonesia. 2016. Kendalikan Kanker Servix Sejak Dini dengan Imunisasi. Retrieved from: www.depkes.go.id

Musa J, Achenbach CJ, O’Dwyer LC, Evans CT, McHugh M, Hou L, et al. 2017. Effect of cervical cancer education and provider recommendation for screening on screening rates: A systematic review and meta-analysis. PLoS ONE 12(9): e0183924. https://doi.org/10.1371/journal. pone.0183924

National Cancer Management Committee. 2014 Panduan Penatalaksanaan Kanker Serviks. Retrieved from kanker.kemkes.go.id/guidelines/PPKServiks. $p d f$.

Ngawai, P., Truadpon, P., Inpa, C., Sangpetngam, B., Mekjarasnapa, M., Apirakarn, M \& Chunworathayi, B. (2007). Knowledge, Attitudes and Practices vis-à-vis Cervical Cancer Among Registered Nurses at the Faculty of Medicine, Khon Kaen University, Thailand. Asian Pacific J Cancer Prev, 9, 15-18

Rahman, H \& Kar, S. 2015. Knowledge, Attitudes and Practice toward Cervical Cancer Screening

Marlina Elfrida Sinaga, dkk., Nurses’'Attitude About Pap Smear,... 
among Sikkimese Nursing Staff in India. Indian Journal of Medical and Paediatric Oncology, Vol 36, Issue 2.

Shekhar,S., Sharma, C., Thakur, T \& Raina, N. 2013. Cervical Cancer Screening: Knowledge, Attitude and Practices among Nursing Staff in a Tertiary Level Teaching Institution of Rural India. Asian Pac J Cancer Prev, 14 (6), 36413645

Sherman SM, Bartholomew K, Denison HJ, Patel H, Moss EL, Douwes J, et al. 2018. Knowledge, attitudes and awareness of the human papillomavirus among health professionals in New Zealand. PLoS ONE 13(12): e0197648. https://doi. org/10.1371/journal.pone.0197648

Thippeveeranna, C., Mohan, S.S., Singh, L.R., Singh, N.N. 2013. Knowledge, Attitude and Practice of the Pap Smear as a Screening Procedure Among Nurses in a Tertiary Hospital in North Eastern India. Asian Pacific J Cancer Prev, 14 (2), pp 849-852.

Udigwe, G.O. 2006. Knowledge, Attitude and Practice of Cervical Canver Screening (PAP Smear) among Female Nurses in Nnewi, South Eastern Nigeria. Nigerian Journal of Clinical Practice, 9 (1): 40-43.

Urasa M, \& Darj E. 2011. Knowledge of cervical cancer and screening practices of nurses at a regional hospital in Tanzania. African Health Sciences. 11(1): 48 - 57.

V. V. Anantharaman, S. Sudharshini, A. Chitra. 2012. A cross-sectional study on knowledge, attitude, and practice on cervical cancer and screening among female health care providers of Chennai corporation. Journal of Academy of Medical Sciences. Vol. 2, Issue 4. 124-128.

World Health Organization. (2015). Estimated Cervical Cancer Incidence Worldwide in 2012. Geneva: World Health Organization.

Young-Mi Kim, Abigael Ati, Adrienne Kols, Fransisca Maria Lambe, Djoko Soetikno, Megan Wysong, Ana Isabel Tergas, Presha Rajbhandari, Enriquito Lu. 2015. Influencing Women's Actions on Cervical Cancer Screening and Treatment in Karawang District, Indonesia. Asian Pacific Journal of Cancer Prevention, Vol 13, pp 2913-2921 